\title{
Critique
}

Journal of Socialist Theory

\section{Under Western Eyes: On Farris's In the Name of Women's Rights}

\section{Baraneh Emadian}

To cite this article: Baraneh Emadian (2019) Under Western Eyes: On Farris's In the Name of Women's Rights, Critique, 47:1, 143-158

To link to this article: https://doi.org/10.1080/03017605.2018.1554762

册 Published online: 07 Jan 2019.

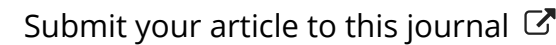

View Crossmark data $₫$ 


\section{Review Essay}

\section{Under Western Eyes: On Farris's In the Name of Women's Rights}

\section{Baraneh Emadian}

This essay reflects upon the category of femonationalism as theorised in Sara Farris's book, In the Name of Women's Rights: The Rise of Femonationalism, with a focus on her critique of theories of populism. Farris's approach, it is argued, productively pinpoints the exceptional position of Muslim and non-western migrant women in the reproduction of the material conditions of social reproduction in western Europe. However, the force of Farris's Marxist theorisation of femonationalism is partly undermined by the absence of any reference to the conditions of the countries these women come from. A critique of neoliberal capitalism, which centres on the problem of Muslim migrant workers in Europe, should not be indifferent to different complex configurations of Islam with capitalism. Furthermore, while Farris's account of the power politics of different factions in Europe and their fusion of reaction and emancipation is invaluable, she does not articulate her insights into a global politics of emancipation or anti-capitalist struggle. In other words, the book does not address the question of how migrant women could attempt to liberate themselves from their 'victimhood' under the conditions lucidly depicted in this book.

KEYWORDS: Femonationalism; Sara R. Farris; Marxist Feminism; Social Reproduction; Populism; Islamophobia; Migrant Workers; Women's Rights

\section{Introduction}

Instrumentalisation of women for reproductive purposes seems to be as old as the original sin and the fall of man. One ancient tale that pops into mind is 'The Abduction of the Sabine Women', the legend of the kidnapping of the Sabine women during the Neptune Equester festival by the early Roman men who needed women to establish families and found a civilisation. Even though these women are forced to make lives for the Roman men, they are looked upon as the Trojan horse of other mores and practices. This story/history lives on, reiterated in various forms and contents throughout 
centuries as we move from biological reproduction to social reproduction and so forth. In the Name of Women's Rights discloses the persistence of this instrumentalisation of women and much more, a dive into the new 'capitalist' days of instrumentalisation yet to come.

The book is a timely reflection on the recent unlikely marriage between xenophobia and emancipatory rhetoric in the West, a phenomenon that, as becomes clear in this article, remains largely unexplored in various theories of populism. Although theories of populism at their best can elucidate the rise of xenophobia in contemporary Europe (exemplified in the rise of anti-immigrant and anti-Islam campaigns) in terms of the 'identification of an enemy against which the populist subject coalesces', ${ }^{1}$ they fail to make sense of the position of immigrant women as exceptions to this rule. In other words, whilst the immigrant Muslim men are viewed as ideological and economic threats to Europeans (misogynists, criminals, and job-stealers), the Muslim women are looked upon as victims who need to be rescued and, tacitly, as potential caregivers that European career women cannot do without. The rise of Islamophobia in the West gives fresh urgency to this new approach to the predicament of immigrant women-with double-emphasis placed on Muslim women ${ }^{2}$-in the neoliberal Europe.

Overall, Farris's multi-faceted approach, which employs femonationalism as the convergence of different political standpoints intimately interwoven with a specific economic logic, is compelling despite a crucial omission-what could be called 'the unthought' of her theory-that will be unfolded in the final section of this essay. The question that guides this essay revolves around whether this work manages to capture what it regards as the failure of theories of populism, the extent to which this work reflects the nuances of the situation (conjunction of different moments of emancipation and reaction, Global South and Global North, etc.).

\section{Sites of Femonationalism}

Farris introduces the term 'femonationalism' as a potent theoretical concept to encapsulate the political and economic agenda of diverse political actors who appropriate the discourse of the women's rights, hence masking an extreme fear of the Other, culminating in Islamophobia. Implicit in femonationalism, which operates as the hinge of the five chapters of the book, are three main theoretical moments: femonationalism as convergence, as ideological formation, and as neoliberal political economy. The notion of convergence captures the intersectional character of femonationalism as the meeting-point among nationalist right-wing parties, certain feminists/femocrats, and many neoliberal policies that give rise to anti-immigrant or anti-Islam campaigns in the Netherlands, France, and Italy (the three countries that comprise the focus of the

\footnotetext{
1 S.R. Farris, In the Name of Women's Rights (Durham and London: Duke University Press, 2017), p. 64.

2 Muslim women play an important role in Farris's analysis, because they can be treated by the western Europeans as victims coming from oppressive cultures. One could surmise that they evoke a form of otherness that is more radical than the otherness of the eastern European women.
} 
study throughout). The category of convergence enables Farris to explain the ideological undercurrents that gather these different groups together (despite their differences) and the interests that lie behind their endorsement of anti-Islam/anti-immigration politics. Following the tendency to name far-right parties like the Partij voor de Vrijheid (Netherlands), the Front National (France), and the Lega Nord (Italy) as 'populists', Farris nonetheless stresses that the concept of populism falls short of disclosing the ideological matrix at the core of these parties' tendency to harp on gender equality within xenophobic campaigns. ${ }^{3}$ In this vein, the argument in Chapter 3 is levelled against commentators who detect no connection between the issue of women's rights, which migrant women are encouraged by the civic integration policies to embrace, and a national paradigm or nationalist upsurge.

Even so, the visibly national articulation of the themes of gender equality and women's rights within the civic integration programmes marks the strengthening of a nationalist and racist trope, which as Farris stresses, is inherent to liberalism. ${ }^{4}$ The inquiry in Chapter 3 into the liberal telos of these policies and their effects on the integration of the non-EU/non-western migrants dovetails into an intricate exploration of the arguments concerning economic liberalism in Chapter 4. It follows that in all the three countries under investigation (France, Netherlands, Italy) the notion of gender equality-particularly in the public sphere-is seemingly espoused, whilst nonwestern countries are implicitly associated with misogynistic practices (polygamy, forced marriages, etc.) and social relations in these countries are contrasted with 'the egalitarian relations' between the sexes in western European countries. ${ }^{5}$

Yet, how does the instrumentalisation of non-western migrant women as cultural reproducers of 'the Nation' take place? Farris explicates how civic integration policies foreground the category of non-western migrant women based on two complementary registers interwoven with nationalist and colonialist ideologies: first, the aforementioned representation of migrant women as injured, vulnerable victims devoid of agency and in need of rescue and shelter; second, migrant women as 'the main carriers of the non-western migrant culture itself, the depositories and reproducers par excellence of its codes, especially on account of their role as mothers' ${ }^{6}$ Let us reformulate Farris's interpretation in the light of a theory of the subject: since every process of resubjectivation is premised on a process of desubjectivation, these policies first desubjectivise migrant women through restatement of their victimisation only in order to resubjectivise them subsequently as agents of the potential assimilation of their migrant communities and the second generation into the western culture. Women thus come to stand for the bearers of what constitutes the nation as the imagined community. ${ }^{7}$ Despite the appearance of nationalist projects or discourses as historically

\footnotetext{
3 S.R. Farris, In the Name of Women's Rights, pp. 57-58.

4 S.R. Farris, In the Name of Women's Rights, p. 81.

${ }^{5}$ S.R. Farris, op. cit., p. 101.

${ }^{6}$ S.R. Farris, op. cit., p. 102.

7 Benedict Anderson, Imagined Communities: Reflections on the Origin and Spread of Nationalism (London: Verso, 2016).
} 
and culturally unique, Farris resorts to Anderson's concept of 'modularity of nationalism' to account for the capacity of these projects to be relocated across time and space. ${ }^{8}$ Hence, femonationalism as an instance of the modular character of the nation and nationalism.

I would like to suggest that this quality of nationalism to be displaced or transplanted through space and time accounts for its enigmatic dimension. As Karatani Kōjin argues, the nation cannot be understood merely in terms of economic or political interest. ${ }^{9}$ Contra Anderson who deems the nation to be a product of Enlightenment rationality, when the rise of the eighteenth century Enlightenment in the West led to a decline in religious modes of thought, Karatani resists this conception of the nation as a substitute for religion. The fact that religions have proved to be more persistent than once imagined does indeed undermine Anderson's thesis. The Enlightenment-not being properly enlightened about itself as Hegel put it-was not able to scorch the root of religion or superstition. ${ }^{10}$ Yet, although universal religions promised immortality to souls, they could not restore the communal temporality (between the past and future generations) that existed in the agrarian community. This communal temporality, Karatani notes, was re-articulated by 'the nation' (at least in imagined form). This explains why nationalisms are epitomised by attachments to both past and future. And it is for this reason that Anderson's conception of the nation as a replacement for religion loses its explanatory power when faced with cases like religious nationalism such as Hindu nationalism in India.

\section{Whither Populism?}

In her assessment of the inability of theories of populism to capture the exceptional position of migrant women in contemporary right-wing discourses in the West, Farris focuses on Ernesto Laclau's category of populism as one of the most thoroughgoing theorisations of this notion. Yet although she is right about the limitations of Laclau's theory (to a degree consequent on its formal approach), ${ }^{11}$ the criticisms thrown out against this theory in a few pages of Chapter 2 contain some oversimplifications. It is productive to shift the lens to these criticisms not simply to be fair to Laclau, but to see whether theories that accuse others of having blind spots caused

\footnotetext{
8 S.R. Farris, op. cit., p. 112.

9 K. Karatani, The Structure of World History. From Modes of Production to Modes of Exchange (Durham and London: Duke University Press, 2014), pp. 213-215.

10 G.W.F. Hegel, Phenomenology of the Mind (New York: Dover Publications, 2003), trans. J.B. Baillie, p. 332.

11 For a critique of Laclau's formalist approach, Farris resorts to Zizek's criticism, suggesting that enumeration of formal conditions are not enough to call a phenomenon populist; what is needed is a consideration of 'the way in which a populist discourse displaces the antagonism and constructs the enemy' (F.R. Farris, op. cit., p. 65; S. Zizek, 'Against the Populist Temptation', Critical Inquiry, 32:(3) (2006), p. 555). For Laclau's reply to Zizek's criticism, see E. Laclau, 'Why Constructing a People is the Main Task of Radical Politics', Critical Inquiry 32:(4) (2006), pp. 646-680. A powerful critique of Laclau's theory can be found in Balibar's Equaliberty (E. Balibar, 'Populism and Politics: The Return of the Contract', in Equaliberty: Political Essays (Durham and London: Duke University Press, 2014)).
} 
by formalism can truly get rid of blind spots through avoidance of a formalist approach. This consideration foreshadows my criticism in the last section of this essay. In brief, I argue that despite Farris's emphasis on 'content', her analysis similarly falls short of grasping the totality of the situation. So, although this exposition will not be exhaustive (as this essay is not on Laclau's theory), it will serve my eventual claim concerning what Farris's book leaves unsaid, what does not find expression in her overall analysis.

First, it is decisive to note that Laclau's treatment of the term 'populism' defies typical usages of this term. Populism in his theory, as Farris also remarks, is the logic of the political. ${ }^{12}$ It is the logic of formation of a people, which in his view is requisite for a universal politics. Since he does not simply employ this term to refer to demagogical, non-egalitarian, and exclusionary politics (as is usually the case), any politics that lacks a potential for universality is not properly populist in his view. Populism par excellence only emerges in democratic politics. ${ }^{13}$ Farris's first objection is levelled against Laclau's notion of 'chain of equivalence' for its obfuscation of 'difference and divisions-in particular, gender differences, but also differences of class, race and sexual orientation ...' ${ }^{14}$ According to Laclau's theory, a chain of equivalence is created when the aims of a particular sector in society are associated with the emancipatory aims of the whole, ${ }^{15}$ because they can overthrow an oppressive part-in the footsteps of Marx, Laclau calls a particular estate in this context as carrying 'the notorious crime of the whole of society, so that liberation from that sphere appears as general self-liberation.' ${ }^{16}$ What different demands have in common is their common opposition to this source of oppression and the frustration of these differential demands creates a spontaneous equivalence among them. ${ }^{17}$ It follows that one demand becomes the signifier of the whole chain, that is, a tendentially empty signifier.

In the best exposition of this schema, Laclau draws on Marx's attribution of this role to the proletariat, a class that is not acknowledged as one and could therefore stand up for all classes. ${ }^{18}$ Laclau stresses that this does not indicate the identification of the aims of a particular group with the others, where universality of the content and formal universality overlaps in the body of the proletariat, but rather a movement beyond the dichotomy universality/particularity. A particularity can only be political once it becomes 'the locus of universalising effects'. ${ }^{19}$ Even so, the universalisation of content is never final; the 'futural horizon of universalisation'

\footnotetext{
12 E. Laclau, On Populist Reason (London: Verso, 2005), p. 117.

13 It is noteworthy, however, that Laclau's populism is not equivalent to communism, as the notion of emancipation remains formal in his theory.

14 S.R. Farris, op. cit., p. 64.

15 E. Laclau, J. Butler, and S. Zizek, Contingency, Hegemony, Universality. Contemporary Dialogues on the Left (London: Verso, 2000), p. 54.

16 Ibid, p. 55.

17 E. Laclau, On Populist Reason (London: Verso, 2005), pp. 73-77; Laclau, 'Why Constructing a People Is the Main Task of Radical Politics', p. 652.

18 Laclau, Butler, and Zizek, op. cit., p. 46.

19 Laclau, Butler, and Zizek, op. cit., p. 56.
} 
remains open-ended. ${ }^{20}$ A particular, without ceasing to be a particular, comes to stand for the universal emancipatory aims of the community. ${ }^{21}$ The empty signifier goes on to preserve the incommensurability between the universal and the particular (which is why it is tendentially or relatively empty), while operating as a short-circuit between them. That is why Rodolphe Gasché notes that Laclau's notion of the empty signifier in politics is comparable to the Hegelian 'concrete abstract or universal', which is by no means reducible to abstractness and formalism. ${ }^{22}$ As such, the logic of politics entails a dialectic of difference and equivalence. The political is a hegemonic battleground opened by a structural lack.

As I maintained above, proper populism in this theory emerges in universal or democratic politics. In other words, the equivalential chain stands for democratic demands. This becomes evident when Laclau steps out of his formalist niche and examines concrete historical events. For instance, he delves into a discussion of the People's Party of America launched in 1892 in St Louis. This platform attempted to describe the deep inequality in the American society at the time and the broad lines of the coalition that would remedy it'. ${ }^{23}$ What followed ultimately was the failure of American populism in 1896 (what Laclau calls the failure of a 'democratic promise') as a result of 'the dissolution of equivalential links and the differential incorporation of sectors [ending up to be hierarchical rather than equalitarian] within a wider organic society- 'transformation', to use Gramsci's term. ${ }^{24}$ The example of Kemalism in Turkey represents an even more limited version of populism in his account, because it conceived the people as 'an a priori homogeneous entity postulated from a centre of power, which instead of being the social precipitate of an equivalential interaction of democratic demands, is seen as determining an identical substance that any demand expresses ... ${ }^{25}$ In this case, because the internal split intrinsic to any democratic demand within the equivalential link disintegrates, the people loses its internal differentiations and is reduced to 'a substantial unity'.

The example of Kemalism is pertinent here, as it brings to light the difference between 'equivalence' and 'identity', meanwhile involving the problem of nationalism, that is, how constitution of a nation is based on the logic of identity. ${ }^{26}$ Laclau's best demonstration of the difference between equivalence and identity can be found in his account of Sorel's notion of 'the general strike'. The myth of the general strike offers an example of a signifier that is not 'tendentially' empty, but is in a sense completely empty, lacking any content whatsoever. ${ }^{27}$ In the myth of general strike, the

\footnotetext{
20 Butler and Laclau, 'The Uses of Equality', Diacritics, 27 (1), (1997).

21 Laclau, Butler, and Zizek, op. cit., p. 46.

22 R. Gasché, 'How Empty Can Empty Be? On the Place of the Universal', in S. Critchley and O. Marchart (eds), Laclau. A Critical Reader (London: Routledge, 2004), pp. 17-35.

23 E. Laclau, On Populist Reason (London: Verso, 2005), pp. 201-208.

24 E. Laclau, op. cit., p. 207.

25 Ibid., p. 208.

26 Ibid., pp. 210-211.

27 In this myth, there are no plurality of places of enunciation, because they all converge to reinforce a unique proletarian identity. No matter whether we are dealing with a demonstration, a strike, or a factory occupation,
} 
revolutionary break does not proceed through the mediation of equivalence, but through absolute identity. ${ }^{28}$ In Laclau's view, this is the kind of populism that informs fascism, for it designates the logic of identity (rather than equivalence) and the emergence of an empty (rather than tendentially empty) signifier. In her criticism, Farris is not sensitive to the fact that the signifier that stands up in a chain of equivalence is not devoid of all content but is tendentially empty. Although relative emptiness decreases the particularity of a signifier, the particularity in its turn reacts by granting to universality an incarnating body. ${ }^{29}$

As such, Laclau's approach to populism in terms of its degrees of success as democratic or universal politics reveals that he is concerned with the theorisation of a post-Marxist theory of democratic politics rather than giving a detailed analysis of this or that specific emancipatory movement. Although I do not believe that postMarxism succeeds in offering us an alternative beyond Marxism, it could be argued that Laclau's On Populist Reason is preoccupied with the Marxian question of formation of grass-roots, egalitarian movements much more than analysing the anatomy of exclusionary politics (eg., different shades of nationalism). Farris, however, does not consider the distinction between equivalence and identity and reduces the first to the second; hence, her interpretation of the 'chain' as a homogenous, undifferentiated 'mass', subsuming difference and divisions. Yet it is crucial to notice that unlike identity, equivalence does not subsume difference, but rather organises differences.

At a more fundamental level, the very claim to equality or equivalence between two or more entities presupposes their difference from one another; otherwise, there would be no equality but only identity. The conflation of the two, however, leads to a misreading of Laclau's theory, and Farris surmises that, as outsiders, non-western migrant women interrupt or interfere in the chain of equivalence that constructs the people as 'one political-national subject'. ${ }^{30}$ This reduction of equivalence to identity leads to overlooking the fact that for Laclau a 'national subject' is not constituted through the logic of equivalence (which involves political antagonism as distinct from the differential structure of a positive social order), but that of identity. Contrary to a self-identical national subject or people [Volk], the people who form a chain of equivalence are not based on the exclusion of migrant women or minorities.

Such valorisation-or even hypostatisation-of difference and division could be enervating in its turn. For how would real change be possible if various particularities were not able to become temporarily indifferent to their differences to come together for a common cause? Any revolutionary change aiming to go beyond anaemic reforms

\footnotetext{
they are all merely preludes to the unique future event of general strike. Laclau compares the emptiness (that is, the complete lack of content) and the infinitude of the task in the idea of 'general strike' to the Kantian notion of 'regulative idea'. For a detailed discussion see E. Laclau, 'Articulation and the Limits of Metaphor', in The Rhetorical Foundations of Society (London: Verso, 2014), pp. 71-74.

28 E. Laclau, op. cit., p. 73.

29 E. Laclau, 'Why Constructing a People Is the Main Task of Radical Politics', p. 647.

30 S.R. Farris, op. cit., pp. 66-67.
} 
-that tend to leave the structure unchanged-would need to suspend (rather than subsume) local, sectorial, and issue-oriented differences. ${ }^{31}$ In the context of Laclau's theory, a kind of 'suture' capable of bringing together divergent demands or forces -in his parlance, a 'chain of equivalence' quilted by a tendentially empty signifieris needed for a real change in the structure to happen. This could be the function of the party (perhaps even People's Party in Gramsci's terms).

Farris eventually draws an analogy between Laclau's formal conception of populism as the construction of the people by means of the creation of an internal frontier and Carl Schmitt's characterisation of the political as grounded on the opposition of friend/enemy. ${ }^{32}$ To Farris, such conceptualisations of politics are based on the exclusion of women, a kind of muscular antagonism in which women would end up playing 'the ancillary role of nurses for injured soldiers' in the Kampfplatz or figure as 'the victor's spoils of war, whereby the male winner humiliates his defeated male counterpart by taking possession of "his" women.'33 The Schmittian 'male-centred' dichotomy accordingly thwarts our understanding as to why right-wing parties as the PVV, FN, and LN mobilise women's rights for their purposes. For lack of space to get into Laclau's theorisation of the category of universality, I will just mention en passant that a glance at his corpus discloses that his reflections on this notion by no means remain confined to the traditional logic of exception.

However, Farris's Derridean take on the Schmittian theory as male-centred is not farfetched. We can also consider Jacques Lacan's formulae of sexuation that discloses how the masculine logic - in contradistinction to the feminine logic of 'not-all'-is a totality that is made through the exclusion of an exception, resonating with the Schmittian conception of universality. ${ }^{34}$ Nonetheless, this does not mean that we can easily discard the idea of construction of a totality based on a constitutive outside. Farris's objection to the Schmittian logic of friend/enemy is an ethical criticism, but at the political level everything revolves around negotiations with the logic of exclusion. In a sense, Derrida can pit this ethical criticism against Schmitt only through distancing himself from politics. ${ }^{35}$ There is no transition from identitarian status to a political one in Derrida's objection to the absence of 'women' in Schmitt's theory.

31 Laclau's approach is in this sense compatible with Alain Badiou's thought. Although the subject and object of political representation are thoroughly deconstructed in Laclau's theory, unlike the advocates of a dismantling of the subject in French philosophy, he regards a certain species of 'the people' (similar to Badiou's 'the collective') as crucial to politics. As Zizek has pointed out, both Badiou and Laclau 'endeavour to conceptualise a new, postCartesian mode of subjectivity which cuts its links with ontology and hinges on a contingent act of decision.' (S. Zizek, The Ticklish Subject: The Absent Centre of Political Ontology (London: Verso, 1999), pp. 172-173.) For a different reading of hegemony that rests upon Gramsci's notion of 'prevision', see P.D. Thomas, 'The Plural Temporalities of Hegemony', Rethinking Marxism: A Journal of Economics, Culture and Society, 29:(2) (2017), pp. 281-302.

${ }^{32}$ S.R Farris, op. cit., p. 65.

33 S.R. Farris, op. cit., p. 66.

34 J. Lacan, Encore: The Seminar of Jacques Lacan, Book XX, on Feminine Sexuality, the Limits of Love and Sexuality - 1972-73 (New York: WW Norton, 1998), pp. 71-77.

35 J. Derrida, The Politics of Friendship (London: Verso, 2005), pp. 155-157. 
In The Poverty of Philosophy, Marx turns to Hegel's statement to reproach Proudhon's optimism toward justice in history: 'History advances by its bad side. ${ }^{36}$ History, so to say, does not proceed by a good side, that is, "by virtue of the intrinsic force and excellence of humanistic ideals' ${ }^{37}$ For better or worse, the Schmittian political insight is successful at capturing this 'bad side' through which history/histories proceed. The masculinist nature of war, a fact unhidden from those who live in war zones, is a historical-political reality captured by the Schmittian theory, and particularly by his conceptualisation of what lies beyond the interiority of one state, that is, its civil and political societies. Schmitt's account of states of exception expresses how the will of the sovereign state-as distinct from or even opposed to the will of citizensrenews itself at the time of crises, not only in real war, but given the very externality of the other, the mere existence of a rival country. ${ }^{38}$ The actuality of friend/enemy dichotomy finds expression in Schmitt's nearly monomaniacal stress on the role of war in inter-state relations.

The eight-year war between Iran and Iraq (1980-1988), which coincided with my childhood and early adolescence in Iran, is one example among many that bring home this point. At the beginning of the war, women who had been largely driven out of the workforce after the establishment of the Islamic Republic in Iran, were brought back to the workforce overnight, not as soldiers, but precisely as cooks and carers for soldiers. ${ }^{39}$ Yet, long after that war, living in the Islamic Republic of Iran continues to be a day-to-day confirmation of the actuality of the political logic of 'Us' and 'Them'. This explains the role countries like Iran or North Korea (each in their own distinct and specific ways) play as 'Rogue States' in the contemporary world-'the new world order' in George H. W. Bush's terms-for western countries. This becomes even more explicit now in the light of Donald Trump's recent voiding of the nuclear deal with Iran. Rogue States occupy the position of the constitutive outside that preserves the unity of the world system. In other words, separation of these countries from the rest of the 'Third World', or the fact that these specific countries rather than others (such as Israel) are barred from nuclear enrichment, has a political bearing. So even when we deal with 'capitalist' states, we cannot neglect this political raison d'être.

On a lighter note, implicit in the book's narrative is the insight that integration of migrant women in western societies as carers is not a genuine act of inclusion, but a variation on the theme of instrumentalisation of the Other, albeit by softer means. ${ }^{40}$ It

\footnotetext{
${ }^{36}$ K. Marx and F. Engels, The Poverty of Philosophy, in Collected Works 1976, p. 174.

37 E. Balibar, The Philosophy of Marx (London: Verso, 2017), trans. C. Turner, p. 98.

38 C. Schmitt, The Nomos of the Earth in the International Law of the Jus Publicum Europaeum (New York: Telos Press, 2003), trans. G.L. Ulmen, p. 141.

39 Tabari and Yeganeh, In the Shadow of Islam. The Women's movement in Iran (London: Zed Books, 1982), pp. 236-237.

40 Farris's narrative is indeed strewn with examples of the contradictory nature of this so-called integration of non-western migrant women. For instance, on the one hand the Muslim women in France are encouraged to communicate with their children's school teachers, while on the other, they are not welcome in public schools or barred from entering them because they wear Hijab or Burqa (p. 99). Moreover, the care and domestic jobs
} 
should not be surprising therefore to argue that, despite being exposed to less ruthless laws and policies than migrant men, migrant women in western countries do not cease to be outsiders. ${ }^{41}$ In a word, we are still within the logic of 'Us' and 'Them,' though in a more nuanced neoliberal form, roughly echoing the distinction between 'old imperialism' and 'new imperialism': though they both involve destruction, the second is soft kill. This is what the different treatment of migrant women from migrant men boils down to.

\section{Beware of the Call to Work}

Evident in the convergence of various motifs in the category of femonationalism is the summoning of non-western migrant women to work. ${ }^{42}$ This is where Farris smells a rat, since liberation from the private sphere through integration in the public sphere once constituted a common denominator for the struggle of western European feminists. Fordism allowed the second-wave feminists to orchestrate a 'pro-work' chorus beyond class divisions. These feminists' call for women's participation in the workforce had therefore been attuned to the desire of most women not to be confined within the bounds of social reproduction and to join the production sphere. Yet, the circumstances largely changed in post-Fordist times in which the participation of women in the labour market became-and continues to be-the order of the day, albeit that this participation involves a great level of inequality and reinforcing both class and racial divisions. Meanwhile, non-western racialised women have become part and parcel of the western European workforce in an unprecedented way. Against this backdrop, encouraging non-western women to join the workforce to promote better assimilation and economic independence is not unifying, but rather contradictory and divisive.

In a sense, non-western migrant women have been offered the very roles that western European feminists abandoned during their march towards liberation. As such, the 'liberatory' appeal of these western groups to save migrant women from their 'oppressive cultures' boils down to further segregation of these women into 'highly gendered and racialised labour markets' ${ }^{43}$ Farris is equally concerned that the plight of these migrant women is not exactly the same as what the second-wave feminists tried to elude, since the social reproductive work migrant women have to undertake now is no longer free/unpaid, but waged. So, although at a first glance it

are 'often performed in unsafe contexts, without contract regulations or health and social benefits and in very abusive working conditions' (p. 179). The picture that emerges is a far cry from real integration or inclusion, despite the deceptive makeover. The situation, I would suggest, could be summed up as such: 'You can enjoy being one of us only as long as you stay away from us.'

${ }^{41}$ I stress that Farris's exposure of the nuances of the situation helps us get a more accurate picture of this state of affairs. Yet her analysis generally does not render the friend/enemy distinction-as the logic of externalisation of the Other-obsolete or less effective.

42 S.R. Farris, op. cit., p. 142.

43 S.R. Farris, op. cit., p. 143. 
may appear that feminist thinkers like Federici and Dalla Costa have succeeded in getting recognition for domestic work as productive work, such waged work eventually fails to get migrant women a step closer to liberation, as it is low-status, defamed or undesired by most western European women, and underpaid. ${ }^{44}$ This is, once again, the old skeleton being masqueraded in new neoliberal garments.

Generally, while the second-wave feminist demand for women to become a part of the workforce made sense in the historical context of the 1960s and 1970s, today's repetition of the same demand vis-à-vis non-western migrant women (as compatible with the present Islamophobic political agenda) leads to a temporal disjunction, which has its roots in the old trope of western supremacy. Today, the reiteration of that demand is tantamount to expecting non-western women who care for liberation to jump on the bandwagon and catch up with western women.

\section{A Critique of Political Economy of Femonationalism}

The last chapter undertakes an analysis of the manifold economic incentives that have shaped femonationalism. Moving beyond a culturalist grasp of neoliberalism, the lens is shifted towards its political-economic reality that consists not only in a (re)organisation of the productive sphere, but also the reproductive one by means of institutionalisation of the femonationalist ideology as part of the operation of the state apparatuses. ${ }^{45}$ Farris employs Marx's well-known concept of the 'reserve army of labour' (the production of a pool of unemployed and underemployed under capitalism) as a theoretical tool to explicate and analyse the specific role of non-western migrant workers in contemporary western European economies. Seeking to distinguish her approach from post-Fordist reformulations of the notion of reserve army, Farris conveys that the amendment of the Marxian treatment of a surpluslabouring population entails a consideration of the specificities of the paid care and domestic work in contemporary western European societies.

Certain characteristics (such as very poor conditions, lack of spatial fixity, low wages and status, and unsocial and irregular hours), which play a part in the relative subtraction of this type of work from capitalist relations, explain its divergence from 'unpaid' social reproduction involving western women (the target of second wave feminists) as well as from the kinds of work chiefly attracting migrant men. Farris then contends:

... the female migrant workforce employed in the care and domestic sector in western Europe amounts not to a reserve army that is depicted (and perceived) as an economic threat to native-born workers, constantly exposed to unemployment and used in order to maintain wage discipline, but to a 'regular' army of labour. ${ }^{46}$

The notion of 'regular army of labour,' coined as a supplement to the Marxian theory of surplus populations, allows Farris to portray the lot of migrant women involved in

\footnotetext{
44 Ibid., p. 137.

45 Ibid., p. 150.

46 Ibid., p. 177.
} 
commodified socially reproductive labour. ${ }^{47}$ The Marxian concept is in this way modified to consider the neglected field of socially reproductive labour and its metamorphoses under neoliberal capitalism. Far from being a mere ideological gloss, the rise of femonationalism and appropriation of the emancipatory discourse of 'women's rights' is the outcome of a particular rearrangement of the labour market and migration as well as the shift towards nationalism that is symptomatic of neoliberal globalisation in the last thirty years. ${ }^{48}$ In short, the mantra of rescuing and liberating the Muslim migrant women in western European countries has mainly to do with their central role in the reproduction of the material conditions of social reproduction.

The arguments of this chapter on the political economic role of femonationalism lay bare the truth-content of the contemporary situation in the West. Yet, to go back to my earlier claim, I will try to shed light on what strikes one as the moment of the 'unthought' in this theory. My arguments will focus on migrant women from Muslim backgrounds for the critical role these women play in Farris's analysis (that is, for femonationalists these women are the ideal objects of salvation from their socalled 'misogynistic cultures'), whilst the present atmosphere of Islamophobia in the West further confounds their position.

\section{Beyond Western Femonationalism?}

Even though the globalisation of capital is a decisive subject in Marxist thought, this globalisation should not be merely abstracted in the movement of capital. Rather, this globalisation must be observed and engaged with in terms of plural forms of capitalist social formations or plural forms of synthesis between capital and the state, capital and religion, capital and pre-capitalist/non-capitalist modes of production, and so on. There is a dialectical tension from the outset between understanding capitalism as a global phenomenon and the very high capacity in capitalism for differentiations and reconfigurations. If a trajectory is to be truly global, it cannot interpret the moment of the global only in terms of economics but must be wary of different forms of fusion of capitalism with various religions, cultures, and forms of government. A critique of neoliberal capitalism, which centres on the problem of Muslim migrant workers in Europe, should not remain indifferent to diverse complex configurations of Islam with capitalism.

Contra to femonationalists whose hypocritical discourse serves the instrumentalisation of non-western women, Farris is concerned with the real ordeal, real suffering, of these women and the problem of gender oppression per se. It is striking then that her analyses have nothing to say about the world these women

\footnotetext{
47 Farris stresses that the term 'regular' does not imply stability; nor does it suggest better, more regulated and secure working conditions for women than for men. Yet, it draws attention to the 'regular' character of migrant women's work in this context as opposed to the position of migrant men who fit in the category of the reserve army of labour (pp. 178-179).

48 Ibid., p. 182.
} 
come from. ${ }^{49}$ For how could the problematic of the Muslim workers in Europe or the dependence of western countries on cheap migrant labour for care work be totally severed from the Middle-Eastern or African side of the dilemma? If the response to this criticism would stress the difficulty of dealing with Muslim countries in this project, then the same could be said in defence of the omissions regarding gender or race in theories of populism that Farris takes issue with (eg., Laclau). However, this is not an empirical but a theoretical shortcoming. This omission is also reflected in the way the category of the state is treated narrowly (revolving around western states alone), partly contributing to a monolithic image of 'Muslim women' in this work. In what remains of this article, I will try to elaborate on my contention.

It is not a coincidence that the state plays an essential role in any discussion vis à vis the Muslims of the Global South, for one of the singular characteristics of Islam in the contemporary times is precisely its interweaving with the state form. Explication of the historical reasons behind this persistent fusion would be the task of another essay, so it should suffice to say that this marriage enjoys all variations from the monarchic and constitutional monarchic 'Islamic states' (Saudi Arabia, the Gulf Arab States) to the 'Islamic Republics' (Islamic Republics of Iran, Pakistan, Afghanistan). Notice that 'Muslim/Islamic state' in this context indicates that the constitutions and legal systems of these states are largely interwoven with Sharia (Islamic Law) and the statist interpretation of the latter controls every aspect of life. Most important, the equality of all citizens is not included in these constitutions. The inferior position of women is therefore part and parcel of the law itself. ${ }^{50}$ What is denied to women by most of these states is not merely women's rights, but the very fundamental right to have rights. Obviously, this is not the problem of Islam as a religion, but an outcome of its fusion with the state. In short, we must fervidly oppose an essentialist approach to Islam or any religion. However, even if we were to accept the thesis of pure contingency (to counter essentialism), we would be equally faced with the 'contingent' reality of the persistence of many 'Islamic/Muslim states' in the contemporary world. In other words, this (contingent) persistence has a historical content that strongly determines its social effects. The oppressive reality of a 'religious state' should not be underestimated.

\footnotetext{
49 This other world is only passingly mentioned-and solely from an economic perspective-in one or two sentences. Citing Saskia Sassen, Farris merely remarks that these women 'go through a process of incorporation into and expulsion from wage labour in their sending countries before they move to richer regions in the North' (Farris, p. 179; S. Sassen, 'Notes on the incorporation of Third World Women into Wage Labour through Immigration and Off-Shore Production', International Migration Review 18 (1984), pp. 1144-1167).

50 So, it appears that atheist or non-religious women who come to the West from Islamic countries are the 'exceptions'. They are placed in a zone of indistinction, at the threshold between inside and outside, and while their existence gives meaning to religious faith (as its constitutive other), they are absent from both Marxist feminist and reactionary accounts. Reactionary and right-wing discourses are interested in the 'practicing' Muslim women as victims (as Farris describes in her book), whilst Marxist feminists focus on the 'practicing' Muslim women to criticise Islamophobia in the West, or, in earlier times, to object to colonialism. One can rarely find Marxist feminist writings that acknowledge the fight or struggle of non-religious or leftist women from the Global South against statist, authoritarian adaptations of Islam.
} 
If we shifted the lens towards a country like Iran for instance, we would observe that thirty-eight years of the reign of an authoritarian Islamic state has alienated a significant part of the population from religion. As a result, the disposition of millions of Iranian women towards a religion whose laws (Sharia) have been dictated to them at gunpoint by the state is not the same as those of Muslim women who grow up in the West as a minority and who perhaps justifiably choose to stick to Islam (in many cases, involving identitarian desires). What is overlooked by many Marxists is that the desire of many Iranian women to get away from Sharia and Hijab is not rooted in Westernisation or fascination with (neo)liberalism or capitalism; rather it is an upshot of the extreme deep-rooted religious suppression implemented by the state.

For better or worse, a great number of these women do not fit into the category of 'practicing' Muslim women (eg., they do not cover), and after immigration to the West they cannot be easily categorised as Muslim women in need of emancipation from the so-called Islamic male chauvinism; their ordeal is therefore not captured by the concept of femonationalism. ${ }^{51}$ Yet, although they do not identify themselves as Muslims, these women are not spared from the marker of the potential 'Muslim enemy'. So, the Schmittian friend/enemy distinction does capture their ordeal. Generally, differences seem to be dissolved in the term 'Muslim', as it has come to designate the abstract category of radical 'Otherness'. There is a tendency to call all women who come from Islamic countries 'Muslim', regardless of their faith in Islam or lack thereof. This is where we approach murky waters and one instance of this blurring of borders is manifested in Donald Trump's list of travel ban to prevent terrorists from entering the US. ${ }^{52}$ Whilst Iranian citizens are included in this list as potential Muslim terrorists, no distinction is made between practicing and non-practicing Muslims /non-Muslim Iranians; the ban is applied to all Iranians, that is, to Baha'i, Christian, or Marxist Iranians as well as the individuals of Islamic faith. What we encounter is a racialised conception of religion.

Overlooking the specific interwovenness of Islam with the state is not devoid of a certain degree of economic reductionism. For instance, it masks the fact that the problem of suppression of women such as mandatory Hijab in many Islamic countries like Iran (which compels many women to immigrate) is not directly connected to the 'capitalist' function of the state, but has much more to do with the constitutive role of the Muslim clergy and the whole convoluted history of the links between the state and religion in the Islamic world. In this context, the problems arising from the religious state are independent of the rise of the capitalist state despite the tendency of the latter for the formal subsumption and reconfiguration of patriarchy. In fact, for a significant

\footnotetext{
51 To clarify, the gender oppression that Iranian women experience is inflicted on them by the state, not necessarily by their families or cultural contact. In Iran, there is a duality between the statist Islam and a culture that in many ways resists and defies it (and is by no means reducible to it). Women who immigrate to the West from this setting would not be a good target for femonationalists.

52 The list (released on 6 March 2017) originally covered seven Muslim-majority countries: Iran, Iraq, Libya, Somalia, Sudan, Syria, and Yemen.
} 
number of Muslim migrant women capitalist exploitation alone is preferable to capitalist exploitation plus oppression by a religious state.

Despite her recognition of the differential treatment of Muslim men and women in Western European societies, Farris is still susceptible to a generalisation and dehistoricisation of Islam and Muslim women. Implicit in her discussion of femonationalism as an ideological formation in the context of the commodification of women is such a homogenisation of Islam. Farris states that in capitalism the female body must be exposed (uncovered) to circulate according to the market paradigm; therefore, the Muslim woman needs 'to show what she's got to sell' (p. 182) ${ }^{53}$ Curiously, this standpoint ignores that capitalism hosts in its midst a plurality of differences. The fact that the Parisian haute couture exhibits Islamic fashion and covered women on catwalks is a proof that capitalism has encountered no obstacles in co-opting covered women and the creation of an Islamic fashion market. In 2011, Reuters reported that Arab women (that is, wealthy women wearing Hijab or Burqa) were the biggest buyers of haute couture. ${ }^{54}$ Thus, the above standpoint arises from a homogenisation of Islam, neglecting the fact that unlike political Islam, a cultural version of Islam could be highly complicit with capitalism.

To reiterate, if we accepted the Marxist view that western capitalism 'would have been impossible without the preceding or accompanying histories of colonial subjugation, Atlantic slavery, and the world market more generally', then a precise analysis of the situation of the migrant Muslim women in the West would have to acknowledge, at least partly, the conditions of the countries they come from and the inextricable relation between religion and the state that predominates in their countries. ${ }^{55}$ To put it another way, to understand the violent synchronisation of divergent temporalities by capital and the state, we need to take into account the forced relation between the organisation of social reproduction through the rampant utilisation of a migrant labour force in western countries and the mechanisms of social reproduction in the countries of origin of (women) migrant workers.

It is also productive to remember the Marxian insight that understanding capitalism as a historical phenomenon depends on the pursuit of a dialectic between unity and multiplicity. In the Name of Women's Rights succeeds in presenting a range of multiplicities in western European countries (mainly the Netherlands, France, and Italy), but fails to inscribe them in such a dialectic. But avoidance of the quagmire of formalism should not be tantamount to a return to sites of politics as fragmented between different local discourses without an attempt at synthesising or articulating them into a

\footnotetext{
53 Farris quotes Alain Badiou on this point. However, in other texts Badiou acknowledges that the logic of capital takes cultural differences as its currency. Eg., A. Badiou, Ethics: An Essay on the Understanding of Evil (London: Verso, 2001), trans. P. Hallward, pp. 112-113.

${ }^{54}$ K. Chrisman-Campbell, 'Why Western Designers Are Embracing the Hijab', online at: www. Theatlantic. com/entertainment/archive/2016/01/dolce-gabbana-high-fashion/423171/ (2016), accessed 20 November 2017; C. Lindholm, 'Cultural Collusion: The Branded Abaya', Fashion, Style and Popular Culture 1:(1) (2014).

${ }^{55} \mathrm{~J}$. Banaji, 'Globalising the History of Capital: Ways Forward', online at www.historicalmaterialism.org/ node/240; accessed 20 November 2017.
} 
universal anti-capitalist struggle or a universal politics of emancipation. Overall, Farris's timely work, which seeks to disclose the power politics of different groups and their fusion of reaction and emancipation, would be further enriched by receptivity to another kind of power relation that exists in the historical background of migrant women from the Global South. Her insights would be strengthened by paying some attention to the similar utilitarian convergence of diverging agendas in the developing countries and similar configurations to western femonationalism that target these women before immigration. Finally, the book would encounter a greater challenge through an engagement with the problem of a universal politics of emancipation. Only under the light of such a universal conception of emancipatory politics could we pose the specific question of how these migrant women could be liberated from their 'victimhood' under the circumstances so perspicuously depicted in this book. 